\title{
Ters Yüz Edilmiş Sınıf Modeliyle Ortaokul Öğrencilerinin Sosyal Bilgiler Dersi Akademik Başarılarının Geliştirilmesi ${ }^{1}$
}

\section{Erdi Erdoğan²}

\author{
Bülent Akbaba ${ }^{3}$
}

\section{Type/Tür:}

Research/Araştırma

Received/Geliş Tarihi:

September 28/ 28 Eylül 2018

Accepted/Kabul Tarihi:

November 22/ 22 Kasim 2018

Page numbers/Sayfa No: 193-213

Corresponding

Author/İletişimden Sorumlu

Yazar:

erdierdogan90@hotmail.com

\section{$\checkmark$ iThenticate}

This paper was checked for plagiarism using iThenticate during the preview process and before publication. / Bu çalışma ön inceleme sürecinde ve yayımlanmadan önce iThenticate yazılımı ile taranmıştır.

Copyright (C) 2019 by

Cumhuriyet University, Faculty of Education. All rights reserved.

\section{Öz}

Teknoloji destekli eğitimin yararlarının fark edilmesi ve harmanlanmış öğrenmenin etkisini arttırmasıyla öğretim sürecinin yapısı değişmekte ve okulun fiziksel sınırları ortadan kalkmaktadır. Böylece ters yüz edilmiş sınıf modeli gibi harmanlanmış öğrenme modelleri ders başarısından, öğrencinin derse yönelik algısına değin birçok alanı farklılaştırıcı etkide bulunmaktadır. Bu çalışma kapsamında da ters yüz edilmiş sınıf modelinin, öğrencilerin 6. sinıf "Sosyal Bilgiler" dersi "İpek Yolunda Türkler" ünitesindeki akademik başarılarında süreç içerisinde nasıl bir değişiklik oluşturduğunu ortaya çıkarmak amaçlanmıştır. Bu araştırma nitel araştırma yaklaşımına uygun olarak tasarlanmıştır. Desen olarak ise eylem araştırması tercih edilmiştir. Araştırmanın çalışma grubunun belirlenmesinde nitel araştırmanın doğasına uygun olarak amaçlı örnekleme yöntemi kullanılmıştır. Böylece 21 öğrenci araştırmaya dâhil edilmiştir. Eylem sürecinde video dersler eğitim içerikli bir paylaşım sitesi aracılığıyla iletilmiş, sınıf içi süreç aktif öğrenme yöntemleriyle sürdürülmüş ve araştırma süreci 9 haftada tamamlanmıştır. Araştırmada veri toplama aracı olarak, eylem araştırmasının esnek yapısından dolayı başarı testi, araştırmacı günlüğü ve öğrenci ürünleri kullanılmıştır. Verilerin analizinde, başarı testi için betimsel istatistikler ve bağıml gruplar t-testi, diğer veri toplama araçları için ise içerik analizinden yararlanılmıştır. Araştırma sonucunda, ters yüz edilmiş sınıf modeliyle yürütülen öğretim sürecinin öğrenci başarılarını geliştirdiğine ulaşılmıştır.

Ters yüz edilmiş sınıf modelinin etkililiği nicel ve karma araştırma yaklaşımlarıyla da test edilmelidir.

Anahtar Kelimeler: Sosyal bilgiler dersi, harmanlanmış öğrenme, ters yüz edilmiş sınıf modeli, eylem araştırması, akademik başarı.

\section{Suggested APA Citation/Önerilen APA Atıf Biçimi:}

Erdoğan, E. ve Akbaba, B. (2019). Ters yüz edilmiş sınıf modeliyle ortaokul öğrencilerinin sosyal bilgiler dersi akademik başarılarının geliştirilmesi. Cumhuriyet International Journal of Education, 8(1), 193-213. http://dx.doi.org/10.30703/cije.465095

\footnotetext{
${ }^{1}$ Bu araştırma Gazi Üniversitesi Eğitim Bilimleri Enstitüsü'nde Doç. Dr. Bülent Akbaba danışmanlığında yürütülen, Erdi Erdoğan tarafından hazırlanan "Sosyal Bilgiler Öğretiminde Ters Yüz Edilmiş Sınıf Modelinin Kullanımı” adlı doktora tezinden üretilmiştir.

2 Arş. Gör. Dr., Kırıkkale Üniversitesi, Eğitim Fakültesi, Türkçe ve Sosyal Bilimler Eğitimi Bölümü, Kırıkkale/Türkiye Res. Assist. Dr., Kırıkkale University, Faculty of Education, Department of Turkish and Social Sciences Education, Kırıkkale/Turkey e-mail: erdierdogan90@hotmail.com ORCID ID: http:/ / orcid.org/0000-0002-3921-575X

${ }_{3}^{3}$ Doç. Dr. Bülent Akbaba, Gazi Üniversitesi, Gazi Eğitim Fakültesi, Türkçe ve Sosyal Bilimler Eğitimi Bölümü, Ankara/Türkiye Assoc. Prof. Dr., Gazi University, Faculty of Gazi Education, Department of Turkish and Social Sciences Education, Ankara/Turkey e-mail: akbaba@gazi.edu.tr ORCID ID: http:/ / orcid.org/0000-0002-1335-3919
} 


\title{
Developing Secondary School Students' Academic Success of Social Studies Course with Flipped Classroom Model
}

\begin{abstract}
By recognizing the benefits of technology-supported education and, increasing the effect of blended learning, the structure of the teaching process changes and physical limits of the school are eliminated. Thus, blended learning models, such as the flipped classroom model, have a differentiating effect on many areas ranging from course achievement to student's perception towards the course. In this study, it is aimed to find out how the flipped classroom model changes the academic success of students in the "Turks in Silk Road" of 6th-grade social studies course. The study was prepared in action research design with a qualitative research approach. The purposive sampling method, which is in accordance with the nature of the qualitative research, was used to determine the study group. Thus, 21 students were included in the study. During the action process, video lessons were delivered through a sharing site with educational content and the in-class process was sustained with active learning methods and the research process was completed in 9 weeks. As a data collection tool, achievement test, research diary, and student products were used because of the flexible structure of action research. In the analysis of the data, descriptive statistics and paired sample $t$ test were used for achievement test and content analysis was used for other data collection tools. As a result of the research, it was found that the teaching process which was carried out with the flipped classroom model improved students' success. The effectiveness of the flipped classroom model should also be tested with quantitative and mixed research approaches.
\end{abstract}

Keywords: Social studies course, blended learning, flipped classroom model, action research, academic success

\section{Giriş}

İnternetin ve çeşitli teknolojilerin yayılım alanı son yıllarda eğitim sürecini hızlı bir şekilde içine almıştır. Böylece, uzun yıllardır devam eden öğrenmenin nasıl daha anlamlı ve etkili bir şekilde gerçekleştirilebileceği sorununun çeşitli teknolojik araçların yardımıyla çözülebileceği düşüncesi eğitim alanında geniş bir yankı uyandırmıştır. Bu varsayımın ardından sistematik bir şekilde gelişen teknolojik araçları öğrenme sürecine dâhil etme çabaları ortaya çıkmıştır. Böylece Toffler (2012) tarafından nitelendirilen üçüncü dalganın, yani bilişim devriminin etkileri devletin resmi okullarına da ulaşmıştır. Teknolojik devrimin etkilerinden biri de harmanlanmış öğrenme adıyla öğrenme süreçlerini etkisi altına almıştır. Harmanlanmış, öğrenmenin ilk ortaya çıkışı kesin olarak bilinmemesine rağmen, 1990'l1 y1llardan itibaren çevrimiçi ortamların öğretim süreçlerine dâhil edilmeye başlandığ1 görülmektedir (Demiralay, 2014). Bu ilk kıvılcımın ardından, harmanlanmış öğrenme de kendi kavramsal kapsamını oluşturmuş ve alan yazına dâhil edilmiştir. Harmanlanmış öğrenmenin tarihsel gelişim süreci, Friesen (2012) tarafından ikiye ayrılmıştır. Bunlardan ilki, 1999 ve 2004 yılları arasını kapsayan, harmanlanmış öğrenme kavramının içeriğinin oluşturulduğu ve farklı tanımların ortaya çıkarıldığı yıllardır. Ardından, 2006 ve 2012 yılları arası ise kavramın kullanılma sıklığının arttığı, kavramsal temelinin sağlamlaştırıldığı ve belirgin bir anlama kavuşturulduğu yıllar olarak nitelendirilmektedir.

Harmanlanmış öğrenme, literatürde karma ve hibrit öğrenme olarak adlandırılsa da özünde e-öğrenme teknolojileriyle birlikte adını duyurmuş olan bir 
öğretim tasarımı yaklaşımı olarak tanımlanmaktadır (Dağ, 2011). Driscoll (2002) ise harmanlanmış öğrenmeyi, internet temelli teknoloji türlerinin birleşimi, farklı pedagojik anlayışların bir birleşimi, öğretim teknolojilerinin farklı türlerini ve yüzyüze öğretim sürecinin birleştirilmesi ve gerçek iş görevleriyle öğretim teknolojilerinin bir karışımı olarak dört farklı açıdan ifade etmektedir. Harmanlanmış öğrenme kavramı, yüz-yüze öğrenme süreçlerinin, çevrimiçi öğrenme süreçleriyle birleştirilmesini ifade etmektedir (Garrison ve Kanuka, 2004; Bonk ve Graham, 2006). Harmanlanmış öğrenme, sadece öğretim sürecinde bir web sitesine girip, bir şeyler göstermek değildir. Harmanlanmış öğrenme, internetin de kullanıldı̆̆1 uzaktan gönderim araçlarının, yüz-yüze öğretim süreçleriyle birleştirilmesidir (Osguthorpe ve Graham, 2003).

Tüm bu tanımlamalara rağmen harmanlanmış öğrenmenin özünü kavrayabilmek için kavramı ortaya çıkaran gerekçelerin titiz bir şekilde değerlendirilmesi gerekmektedir. Bu kapsamda yüz-yüze öğretim sürecinin aksayan yönlerine bakıldığında, zaman yetersizliği, öğrencinin bilgiyi kalıcı hale getirememesi, dersi kaçırmanın telafi edilemezliği, öğrencilerin dikkatinin çekilememesi, her şeyi öğretmenin gerçekleştirdiği bir öğretim süreci vb. gibi birçok şikâyet edilen durumla karşılaşılmaktadır. Yüz-yüze öğretim sürecinde olduğu gibi sadece uzaktan gönderim araçlarıyla çevrimiçi ortamlarda yürütülen öğretim süreçlerinde de sorunlarla karşılaşılmaktadır. Bunlar, kişiler arası etkileşimin sınırlı olması ve bunun sonucunda yaşanan motivasyon düşüklüğü, açıklama, yorumlama ve belirginleştirme gibi süreçlerin öğretmenle daha kolay gerçekleştirilmesi, bireylerin iletişim kurma becerilerini geliştirmenin güçlüğü, kopya çekme ve bilgi kopyalama sorunu, bireylerin sosyalleşme sorunu yaşaması, öğretmenin öğretim sürecini yönetmesini sinırlayabilmesi ve uygulama gerektiren durumlarda kullanımının zorluğu şeklinde sıralanabilir (Molinari, 2003; Osguthorpe ve Graham, 2003; Bouhnik ve Marcus, 2006; Arkorful ve Abaidoo, 2015). Bu nedenlerden dolay1 harmanlanmış öğrenme günümüz öğretim süreçlerinin önemli bir parçası haline gelmiştir. Bu öğretim tasarımı yaklaşımının en sık kullanılan modellerinden biri olarak ise ters yüz edilmiş sınıf modeli literatürde kendine yer edinmiştir.

\section{Ters Yüz Edilmiş Sınıf Modeli}

Eğitim ve öğretim süreçlerine teknolojik bir destek sağlama açısından literatür incelendiğinde, özellikle harmanlanmış öğrenmenin popülerliğini arttırmasıyla birlikte ters yüz edilmiş sınıf modeli ön plana çıkmıştır. Bu model, eğitimin bileşenlerinin yüz-yüze öğretim sürecinin eksikliklerini daha net ortaya koymasıyla, son yıllarda eğitim alanında dikkatleri üzerine çekmiştir. Her ne kadar ters yüz edilmiş sınıf modelinin 2007-2008 yıllarında Jonathan Bergmann ve Aaron Sams tarafından ortaya çıkarıldığı belirtilse de, bu durumun arka planı daha eski yıllara dayanmaktadır. Gelişim süreci incelendiğinde, ters yüz edilmiş sınıf modelinin temellerinin Miami Üniversitesi'ndeki bir grup profesör tarafından atıldı ̆̆ görülmektedir (Lage, Platt ve Treglia, 2000). Ayrıca bu modelin teknoloji destekli halinden uzak olsa da işletme, hukuk ve beşeri bilimler alanında, öğrencilere okumaları gereken içeriğin verilmesi, ders öncesi bunların okunması ve derste ise tartışmalarla sürecin devam ettirilmesi şeklinde uzun yıllardır kullanıldığ görülmektedir (Talbert, 2012). Bu gelişim sürecinde, modelin 1990'lı yıllarda ise Eric 
Mazur tarafından Harvard Üniversitesi'nde uygulandığı bilinmektedir (Missildine, Fountain, Summers ve Gosselin, 2013). Fakat ters yüz edilmiş sınıfların günümüzde kullanıldı ğı şekliyle ortaya çıkması, Jonathan Bergmann ve Aaron Sams tarafından 2007-2008 eğitim-öğretim yılında kullanılmasına denk gelmektedir.

Ters yüz edilmiş sınıf modelinin uygulama süreci günümüz geleneksel öğretim süreciyle neredeyse zıt bir açıdadır. Öğretmen merkezli geleneksel öğretim sürecinde, sınıf içinde gerekli bilgiler aktarılır ve kavramlar tanıtılır, evde ise öğrencilerden kendilerine verilen ödevleri tamamlamaları istenir. Ters yüz edilmiş sinıf modelinde ise öğrenciler derse gelmeden önce dersle ilgili kavramlarla ve gerekli içerikle karşılaşmaktadırlar. Sınıf içi uygulama sürecinde ise ödevlerini tamamlayarak, izledikleri içerikle ilgili problemleri çözerek ve aktif öğrenme yöntem ve teknikleriyle anlamlı öğrenmeleri gerçekleştirmektedirler (Love, Hodge, Corritore ve Ernst, 2015; Lage, Platt ve Treglia, 2000; Hwang, Lai ve Wang, 2015; Lo ve Hew, 2017). Ters yüz edilmiş sınıf modelinde öğrenciler, evde kendilerine sağlanan içeriği incelemekte, okulda ise öğretmenlerinin rehberliğinde aktif öğrenme yöntem/teknikleriyle sınıf içi uygulama süreçlerine katılmakta ve sorumlu oldukları ödevlerini tamamlamaktadırlar. Bu durum, ters yüz edilmiş sınıf modelinde çevrimiçi ortam kullanımı ve yüz-yüze öğretim sürecinin birleştirildiğinin bir göstergesidir. Böylece hem yüz yüze eğitim sürecinin kısıtlayıcı yapısından kaçınılmakta hem de uzaktan eğitim sürecinin yapaylaştırıcı etkisinden kurtuluş sağlanmaktadır.

Bu kapsamda bakıldığında, birçok disiplini bünyesinde barındırma, zaman yetersizliği, tekrar etme sorunu, aktif öğrenme yetersizliği, yoğun içeriğin bulunması, öğrencinin öğrenme hızına göre hareket edememe gibi sosyal bilgiler öğretimindeki sorunlardan dolayı ters yüz edilmiş sınıf modelinin uygulanmasının öğretim sürecine fayda sağlayacağı düşünülmektedir. Bu açıdan bu araştırmanın amac1; ters yüz edilmiş sınıf modelinin, öğrencilerin 6. sınıf "Sosyal Bilgiler" dersi "İpek Yolunda Türkler" ünitesindeki akademik başarılarında süreç içerisinde nasıl bir değişiklik oluşturduğunu ortaya çıkarmaktır. Ulusal literatüre ters yüz edilmiş sınıf modeliyle gerçekleştirilen araştırmalar açısından bakıldığında, ortaokul düzeyinden lisans eğitimi sürecine değin araştırmalar bulunmasına rağmen bunların sayısının oldukça az olduğuna ulaş1lmıştır (Gençer, 2015; Turan ve Göktaş; 2015; Göğebakan-Yıldız, Kıyıcı ve Altıntaş, 2016; Kocabatmaz, 2016; Cukurbasi ve Kiyici, 2017; Akgün ve Atıc1, 2017; Köse ve Acar, 2017; Çakır ve Yaman, 2017; Erdogan ve Akbaba, 2018). Uluslararası literatürde ise ters yüz edilmiş sınıf modeliyle ilgili daha fazla araştırma gerçekleştirildiği görülmektedir (Snyder, Paska ve Besozzi, 2014; Hultén ve Larsson, 2016; Unruh, Peters ve Willis, 2016; Zainuddin ve Attaran, 2016; Aidinopoulou ve Sampson, 2017; Lo ve Hew, 2017; Latif, Matzin, Jawawi, Mahadi, Jaidin, Mundia ve Shahrill, 2017; Winter, 2018). Tüm bu çalışmalara rağmen ters yüz edilmiş sınıf modeli ve sosyal bilgiler eğitimi alanındaki çalışmaların oldukça az, ulusal literatürde ise sosyal bilgiler dersi kapsaminda "İpek Yolu'nda Türkler" ünitesine ilişkin herhangi bir çalışmaya rastlanılmadığına ulaşılmıştır. Böylece hem bu eksikliği doldurmak hem de ters yüz edilmiş sınıf modelini sosyal bilgiler dersi başarısını geliştirebilme durumunu incelemek nedenleriyle bu araştırma gerçekleştirilmiştir. 


\section{Araştırma Modeli}

\section{Yöntem}

$\mathrm{Bu}$ araştırma nitel araştırma yaklaşımına uygun olarak tasarlanmıştır. Nitel araştırma yaklaşımı, gerek günümüz paradigma değişimi hareketinden gerek standart ölçümler kullanan nicel araştırma yaklaşımının sorgulanmaya başlanmasından gerekse odaklanılan araştırma problemine derinlemesine bir bakışın istenmesi gibi nedenlerle sıklıkla kullanılmaya başlanmıştır. Nitel araştırma, Patton (2014) tarafından da belirtildiği üzere problemin derinlemesine ve ayrıntılı olarak incelenmesine yönelik bir araştırma yaklaşımıdır. Nitel araştırma, metin ve imgesel verileri merkeze alarak, özgün analizleriyle bir durumun, olgunun, konunun, olayın derinlemesine incelenmesini sağlar (Creswell, 2013). Bu araştırma kapsamında, ters yüz edilmiş sınıf modeliyle öğrencilerin sosyal bilgiler dersine yönelik akademik başarılarının geliştirilmesi amaçlandığı için nitel araştırma yaklaşımının bir deseni olan eylem araştırmasından yararlanılmıştır.

Eylem araştırması, temelleri Kurt Lewin tarafından atılan (McNiff, 2000), II. Dünya Savaşı sonrası ortaya çıkan sosyal problemlere bir çözüm bulma ve yeni düzenin gereklerini sağlamak için belirmiş bir nitel araştırma desenidir (Mills, 2007, s.5). Lewin'in bu yöntemi araştırmalarında kullanmasının ardından, eylem araştırması birçok alana dâhil olduğu gibi eğitim araştırmalarına da dâhil edilmiş ve eğitim-öğretim sürecinin niteliğinin geliştirilmesine önemli katkılarda bulunan bir nitel araştırma deseni olarak kendine yer edinmiştir. Eylem araştırması literatürde farklı açılardan tanımlanmıştır. Fakat tüm bu tanımların, sorunları çözmek ve var olan durumu/uygulamayı geliştirmek olmak üzere iki temel vurgu üzerinde örtüştükleri görülmektedir. Bu açıdan bakıldığında, eylem araştırması, katılımcıların durumunu iyileştirmek için çeşitli paydaşların katılımıyla birlikte gerçekleştirilen bir sosyal araştırma olarak tanımlanabilir (Greenwood ve Levin, 2007, s.3). Eylem araştırması, eğitim alanında uygulama sürecinde karşılaşılan sorunları çözmek ve uygulamayı geliştirmek amacıyla kullanılan bir araştırma türüdür (Glesne, 2015).

Temel olarak, bir problem durumunu ortadan kaldırmaya ya da uygulama sürecini geliştirmeyi amaçlayan eylem araştırması kendi içinde de farklı türlere ayrılmaktadır. Bu kapsamda, Berg (2001) tarafından ortaya konulan, teknik/bilimsel/işbirlikli eylem araştırması bu araştırmanın temel metodolojisini oluşturmaktadır. Teknik/bilimsel/işbirlikli eylem araştırması, daha önceden teorik zemini oluşturulmuş bir uygulamayı test etmeyi amaçlayan, araştırmacı ve uygulayıcı arasında işbirliğini gerektiren bir eylem araştırması türü olarak tanımlanmaktadır (Berg, 2001). Bu araştırmada ise teknik/bilimsel/işbirlikli eylem araştırması, ters yüz edilmiş sınıf modeli ile öğrencilerin akademik başarılarının geliştirilmesi amacıyla kullanılmıştır.

\section{Çalışma Grubu}

Nitel araştırmanın doğasında yorumlayıcı bir anlayış bulunduğundan dolayı çalışma grubunun seçimi de nicel araştırmalardan farklılık göstermektedir. $\mathrm{Bu}$ açıdan bakıldığında, nitel araştırmalarda büyük örneklem gruplarıyla çalışılıp, evrene ilişkin genellemeler yapmak yerine, belirli özellikleri tanımlanmış, küçük gruplar üzerinde çalışılmaktadır. Bu nedenle, nitel araştırmalarda çalışma grubu, belirli ölçütler içermelidir. Durumun, uygulamanın ya da çalışma grubunun, genel kabullerden farklı tarafları nitel araştırma yaklaşımının temelini oluşturmaktadır. Bu doğrultuda 
bakıldığında, nitel araştırmanın doğasında çalışma grubu seçiminde amaçlı örneklem yönteminin bulunduğu görülmektedir (Patton, 2014). Bu araştırma kapsamında da çalışma grubunun seçiminde amaçlı örnekleme yönteminden yararlanılmıştır. Böylece araştırmanın amacına uygun olarak, araştırmaya katılacak öğrencilerin, araştırma kapsamında gerekli olan teknolojik donanım imkânlarına sahip olmaları ve öğretmen ve çalışma grubunun araştırmaya gönüllü olarak katılmak istemesi dikkate alınmış, bu şartların sağlanmasıyla çalışma grubu belirlenmiştir.

Bu kapsamda, Türkiye'nin İç Anadolu bölgesinde yer alan bir ilin ortaokul altıncı sınıfında öğrenimine devam eden 11'i erkek, 10'u kız olmak üzere 21 öğrenci araştırma sürecine dâhil edilmiştir. Öğrenciler, veri analizinde kimliklerin gizlenmesi amacıyla Ö1, Ö2 şeklinde kodlanmışlardır. Gönüllü katılımlarıyla araştırma sürecine dâhil olan öğrenciler, video ders ve sınıf içi öğretim süreci hakkında araştırma öncesinde bilgilendirilmişlerdir. Araştırmada sınıf içi uygulamaları yürüten öğretmen ise 10 yıllık bir mesleki deneyime sahiptir. Cinsiyeti erkek olan öğretmen, lisans eğitimini bir devlet üniversitesinin sosyal bilgiler öğretmenliği anabilim dalında tamamlamıştır. Araştırma sürecine katılımda istekli olduğunu belirten öğretmen, sınıfında teknoloji destekli bir öğretim sürecinin sağlanması konusunda istekli davranmıştır. Gönüllü katılımıyla araştırma sürecine dâhil olan öğretmen, eylem planlarının hazırlanmasında, revize edilmesinde ve eylem planlarının sınıf içinde uygulanmasında araştırma sürecine önemli katkılarda bulunmuştur.

\section{Eylem Süreci}

Çalışma grubunun belirlenmesinin ardından, araştırmanın eylem grubu oluşturulmuştur. Eylem grubu, 1 akademisyen, 1 araştırmacı ve 2 öğretmenden oluşmaktadır. Ardından eylem grubuyla birlikte öğrencilerin başarılarının nasıl arttırılabileceğine yönelik görüş alışverişi gerçekleştirilmiş ve 9 haftalık eylem sürecinin planlanmasına gidilmiştir. Böylece eş zamanlı olarak hem teorik aktarımın yapılacağı video derslerin çekimine başlanmış hem de sınıf içi uygulama sürecine yönelik aktif öğrenme yöntem ve tekniklerini içeren ders planlarının geliştirilmesi sağlanmıştır. Bu süreçte geliştirilen video dersler ve ders planları eylem grubunun görüşüne sunulmuş ve istenilen düzeltmeler gerçekleştirilmiştir. Böylece video dersler ve sınıf içi uygulama süreci titiz bir şekilde oluşturulmuştur. Eylem sürecinin başlatılmasından önce, son olarak öğrencilere video dersleri izleyebilecekleri eğitim içerikli bir paylaşım sitesi olan "edpuzzle.com" hakkında iki ders saati boyunca eğitim verilmiştir. Eğitimin ikinci dersi bilişim sınıfında yürütülmüştür. Burada öğrencilere edpuzzle.com sitesinde kullanmaları gereken kullanıcı adları ve şifreleri dağıtılmış, ardından öğrencilerin ilk hafta videosuna bireysel olarak ulaşmalarının bir uygulaması yapılmıştır. Böylece video derslerin izlenebileceği ortam öğrencilere tanıtılmıştır. Eylem süreci öncesi tüm ön hazırlıklar tamamlanmış ve araştırmanın uygulama süreci başlatılmıştır. 


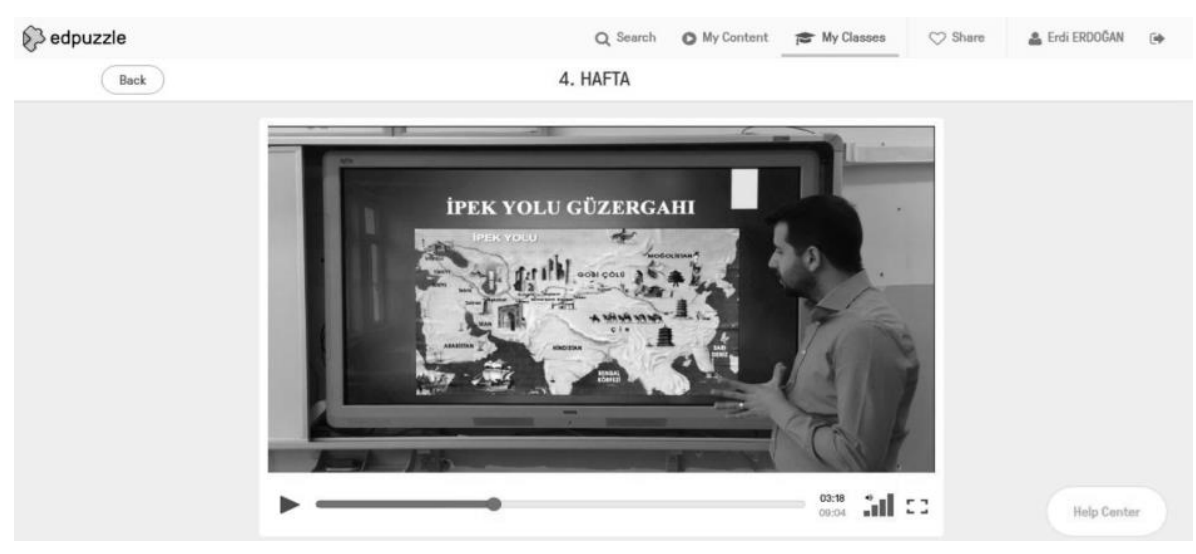

Şekil 1. Video dersten örnek bir görüntü

\section{Veri Toplama Araçları}

Başarı testi. Araştırma sürecinde, öğrencilerin akademik başarıları, akademik başarı testi ile ölçülmüş̧tür. Eylem araştırması süreci gerekli görüldüğünde nicel veri toplama araçlarını da işe koşabilen bir yapıdadır (Gürgür, 2016). Bu araştırma kapsamında da öğrencilerin sosyal bilgiler dersi başarılarını belirlemek için 6. sınıf sosyal bilgiler dersi "İpek Yolunda Türkler" ünitesine ilişkin akademik başarı testi geliştirilmiştir. Bu süreçte ilk olarak "İpek Yolu'nda Türkler" ünitesine ilişkin olarak, kapsam geçerliğini sağlamak amacıyla bir belirtke tablosu hazırlanmıştır (Tavşanc1l, 2006). Belirtke tablosuna uygun olarak 48 çoktan seçmeli (3 çeldirici, 1 doğru cevap) sorudan oluşan ve ünite kapsamındaki tüm kazanımları kapsayan bir başarı testi taslağı oluşturulmuştur. Oluşturulan taslak, farklı üniversitelerin sosyal bilgiler eğitimi anabilim dallarında görev yapan 2 alan uzmanına, 1 sosyal bilgiler öğretmenine, 1 dil uzmanına ve 1 ölçme-değerlendirme uzmanına sunulmuştur. Alan uzmanlarının dönütleri sonucunda, bazı maddelerin çıkartılması istenmiş, böylece taslak form 37 maddeye indirgenmiştir. Başarı testinin pilot uygulaması araştırmanın gerçekleştirileceği ilin merkezinde yer alan bir ortaokulda, 22 Mayıs - 2 Haziran 2017 tarihleri arasında 114 öğrenci üzerinde gerçekleştirilmiştir. Elde edilen araştırma verileri "ITEMAN" programı aracılığı ile incelenmiştir. Toplanılan verilerin analizinin ardından, her çoktan seçmeli maddeye ilişkin olarak madde güçlük indisi (pj) ve madde ayırt edicilik gücü indisi (rjx) hesaplanmıştır. Pilot uygulama sonucunda gerçekleştirilen analiz sürecinde, soruların madde güçlük değerlerinin 0.4 ile 0.6 arasında olmasına, madde ayırt edicilik değerlerinin ise 0.3 değerinden büyük olmasına dikkat edilmiştir. Madde analizlerinin yapılmasının ardından, İpek Yolu'nda Türkler Ünitesi Başarı Testi'nden 9 madde çıkartılarak, başarı testi 28 maddeye indirgenmiştir. Nihai halini alan testin ortalama madde güçlük indisi .49 , madde ayırt edicilik indisi ise .51 olarak hesaplanmıştır. Ayrıca başarı testinin güvenirlik katsayısı olan KR-20 güvenirlik katsayısı ise 0.85 olarak bulunmuştur.

Araştırmacı günlüğü. Eylem araştırmasında önemli noktalardan biri süreç boyunca detaylı olarak veri toplanması ve eş zamanlı olarak analiz edilmesidir. Böylece, eylem araştırması sürecinin etkililiği, süreç içerisinde karşılaşılan sorunlar ve çözüm önerileri detaylıca incelenebilmektedir. Araştırmacı günlüğü de sistematik olarak veri toplama sürecinde önemli rol üstlenen veri toplama araçlarından biridir. 
Araştırmacı günlüğü, araştırmacının özgün ifadelerinden yararlanılarak oluşturulan, uygulama sürecinin sistematik olarak yansıtılmasını ve araştırmacının sürece ilişkin hislerinin ortaya çıkarılmasını sağlayan bir veri toplama aracıdır (Mills, 2007). Araştırmacı, günlüğünü tutarak sınıf içindeki süreci yazılı hale getirir, böylece süreci tekrar inceleyebilir, analiz edebilir ve değerlendirebilir (Cochran-Smith ve Lytle, 1993). Bu durum araştırmacıya esneklik sağlamakta, sürecin titiz ve gerekli görülen tekrar sayılarıyla yeniden incelenmesini mümkün kılmaktadır. Bu nedenden dolayı, bu araştırma kapsamında da araştırmacı tarafından her uygulamanın ardından günlük tutulmuş, döngü yeniden incelenerek değerlendirilmiştir.

Öğrenci ürünleri. Araştırmada kullanılan diğer bir veri toplama aracı, öğrenci ürünleridir. Araştırmada akademik başarı bulgularına destekleyici bir veri toplama aracı olarak hizmet eden öğrenci ürünleri, verilerin üçgenlenmesi sürecinde de önemli bir rol oynamıştır. Öğrenci ürünleri, eylem süreci boyunca öğrencilerden toplanmış, korunmuş ve dijital ortama aktarılmıştır. Böylece başarı testi ve araştırmacı günlüğü gibi veri toplama araçlarının farklı bir veri toplama aracıyla desteklenmesine ve araştırmanın inandırıcılığının arttırılmasına katkı sağlanmıştır.

\section{Verilerin Analizi}

Araştırma verilerinin analizinde hem nicel hem de nitel analiz yöntemlerinden yararlanılmıştır. Bu açıdan, araştırmanın ilk veri toplama aracı olan İpek Yolu'nda Türkler Ünitesi Akademik Başarı Testinin analizinde nicel analiz yöntemlerinden yararlanılmıştır. Bu sürecin ilk adımı olarak, araştırma öncesi ve araştırma sonucunda toplanan verilerin istatistik paket programına girişi sağlanmıştır. Ardından, öğrencilerin öntest, sontest ve fark puanlarını gösteren betimsel istatistiklerin hesaplanması gerçekleştirilmiştir. Betimsel istatistiklerin oluşturulmasının ardından, öntest ve sontest verilerinin analizinde parametrik ya da parametrik olmayan testlerden hangisinin kullanılacağına karar vermek için normallik testi gerçekleştirilmiştir. Normallik testinde verilerin normal dağıldı ğının anlaşılmasıyla parametrik bir testin kullanılmasına karar verilmiştir. Hangi parametrik testin uygulanacağı kararlaştırıldıktan sonra, bağımlı örneklem t-testi veri setine uygulanmıştır. Uygulama sonucunda ortaya çıkan anlamlı farklılık durumu bulgular bölümünde sunulmuştur.

Öğrencilerin süreç içindeki akademik başarılarının değişimini ortaya çıkarmak için kullanılan diğer veri toplama araçları araştırmacı günlüğü ve öğrenci ürünleridir. Bu veri toplama araçlarından elde edilen verilerin analizinde ise eylem araştırmasının doğasına uygun olan sistematik analitik analiz yaklaşımından yararlanılmıştır. Sistematik analitik analiz yaklaşımında, veriler alındıktan sonra hızlı bir şekilde incelenir ve araştırma sorularıyla karşılaştırılması yapılır (Gürgür, 2016). Bu analiz yaklaşımının aşamaları Miles ve Huberman (1994) tarafından, verilerin okunması, verilerin seçilmesi, verilerin bulgulara dönüştürülmesi ve verilerin yorumlanması olarak belirtilmiştir. Böylece eylem sürecinin uygulama aşamasında değerlendirilmesi sağlanarak, ek eylemlere gerek duyulup, duyulmadiğı konusunda eylem grubuna bir değerlendirme şansı yaratılmıştır.

Sistematik analitik analiz sürecinde bulunan verilerin çözümlenmesinde ise içerik analizi tekniğinden yararlanılmıştır. Bu bağlamda bakıldığında, içerik analizi, verilerin içinde saklı olan gerçeklerin ortaya çıkarılmasını sağlayan bir nitel analiz türüdür (Yıldırım ve Şimşek, 2013). İçerik analizi süreci Patton (2014) tarafından ise 
nitel verileri temel alarak tutarlılıkları ve anlamları ortaya çıkarma girişimi olarak nitelendirilmektedir. Bu konu hakkında Robson (2015) ise, içerik analizinin 5 temel aşamadan oluştuğunu belirtmiştir. Bu aşamalar, veri ile tanışmak, ilk kodları üretmek, temaları belirlemek, tematik ağlar oluşturmak, bütünleştirme ve yorumlama olarak ifade edilmiştir. Bu kapsamda, araştırmanın akademik başarıya yönelik nitel veri toplama araçları olan araştırmacı günlüğü ve öğrencileri ürünleri verilerinin çözümlenmesinde içerik analizinden yararlanılmıştır. Doğrudan alıntılarla desteklenen bulgular, okuyucuların görüşlerine sunulmuştur.

\section{Bulgular}

Araştırmanın bu bölümünde, eylem sürecinde yer alan öğrencilerin akademik başarılarının süreç içindeki değişimi çeşitli veri toplama araçlarıyla ortaya konulmak istenmiştir. Bu kapsamda, akademik başarı testi, araştırmacı günlüğü ve öğrenci ürünlerine ilişkin veriler analiz edilmiş ve öğrencilerin sosyal bilgiler dersi başarısına yönelik gelişimleri ortaya çıkarılmıştır.

Tablo 1.

İpek Yolu'nda Türkler Ünitesi Başarn Testinden Alınan Öğrenci Puanlanna İlişkin Betimsel İstatistikler

\begin{tabular}{lccc}
\hline Sira & Öntest & Sontest & Fark Puan \\
\hline Ö1 & 32.14 & 71.43 & 39.29 \\
Ö2 & 32.14 & 75.00 & 42.86 \\
Ö3 & 32.14 & 71.43 & 39.29 \\
Ö4 & 32.14 & 75.00 & 42.86 \\
Ö5 & 39.29 & 75.29 & 50.00 \\
Ö6 & 39.00 & 35.71 \\
Ö7 & 71.43 & 42.86 \\
Ö8 & 28.57 & 78.57 & 39.29 \\
Ö9 & 39.23 & 82.14 & 50.00 \\
Ö10 & 32.14 & 78.57 & 42.86 \\
Ö11 & 35.71 & 71.43 & 39.29 \\
Ö12 & 32.14 & 96.43 & 46.43 \\
Ö13 & 75.00 & 42.86 \\
Ö14 & 50.00 & 78.57 & 42.86 \\
Ö15 & 32.14 & 85.71 & 53.57 \\
Ö16 & 35.71 & 85.71 & 46.43 \\
Ö17 & 32.14 & 89.29 & 42.86 \\
Ö18 & 39.29 & 92.86 & 46.43 \\
Ö19 & 46.43 & 75.00 & 35.71 \\
Ö20 & 46.43 & 71.43 & 35.71 \\
Ö21 & 39.29 & 75.00 & 42.86 \\
\hline Ortalama & 35.71 & 79.25 & 42.86 \\
\hline
\end{tabular}

Tablo 1'de yer alan araştırmanin öntest, sontest ve fark puanlarına bakıldığında öğrencilerin akademik başarı testinden aldıkları puanların dikkate değer şekilde değiştiği görülmektedir. Öğrenci puanları incelendiğinde, araştırma öncesinde $O=36.39$ olarak gerçekleşen puan ortalaması, araştırmanın uygulama süreci sonunda $O=79.25$ olarak gerçekleşmiştir. Araştırmanın öntest ve sontest fark 
puanları incelendiğinde ise iki uygulama arasında $O=42.86$ gibi bir farklılı̆̆ın ortaya çıktığ1 görülmektedir. Bu durum, ters yüz edilmiş sınıf modeliyle sürdürülen sosyal bilgiler dersinin, öğrencilerin akademik başarılarında önemli bir farklılık yarattığının göstergesidir.

Tablo 2.

İpek Yolunda Türkler Ünitesi Başarı Testinden Alınan Ortalama Puanların Öntest ve Sontest Karşılaştırmasına Yönelik Bağımlı Örneklem t-testi Sonuçları

\begin{tabular}{ccccccc}
\hline Ölçüm & $\mathrm{N}$ & $\mathrm{O}$ & $\mathrm{S}$ & $\mathrm{sd}$ & $\mathrm{t}$ & $\mathrm{p}$ \\
\hline Öntest & 21 & 36.39 & 5.72 & 20 & 40.99 & .000 \\
Sontest & 21 & 79.25 & 7.71 & & & \\
\hline
\end{tabular}

Tablo 2'de öğrencilerin öntest ve sontest ortalama puanlarının bağımlı örneklem t-testi aracılığıyla karşılaştırılmasının sonuçları sunulmuştur. Bu bulgulara bakıldığında, öğrencilerin ters yüz edilmiş sınıf modelinin kullanıldığı öğretim süreci sonucunda İpek Yolu'nda Türkler Ünitesi'ne yönelik akademik başarılarının anlamlı bir şekilde arttığ saptanmıştır, $(\mathrm{t}(20)=40.99, \mathrm{p}<.05)$. Öğrencilerin ters yüz edilmiş sınıf modelinin kullanıldığı uygulama süreci öncesi akademik başarı testinden aldıkları puanların ortalaması $O=36.39$ olarak gerçekleşirken, uygulama sonrası $O=79.25$ olarak gerçekleşmiştir. Bu durum, sontest puanları lehine anlamlı bir farklılık yaratmıştır. Böylece öğrencilerin sosyal bilgiler dersindeki başarılarının arttığ1 saptanmıştır. Bu bulgu, ters yüz edilmiş sınıf modelinin, öğrencilerin sosyal bilgiler dersine yönelik başarılarını arttırmada dikkate değer bir rol oynadı̆̆ını göstermektedir.

Araştırma kapsamında, öğrencilerin akademik başarılarındaki gelişimi ortaya çıkarmak amacıyla diğer veri toplama araçları olarak araştırmacı günlüğü ve öğrenci ürünleri kullanılmıştır. Araştırmacı günlüğü ve öğrenci ürünlerinin kullanım amacı, öğrencilerin akademik başarı testinden aldıkları puanları farklı veri toplama araçlarıyla desteklemek, böylece akademik başarıya yönelik veriler arasında tutarlılığı sağlamaktır. Araştırmanın uygulama süreci boyunca tüm uygulamalar için araştırmacı günlüğü tutulmuş, öğrenci ürünleri de ders sonlarında sınıftan toplanarak, saklanmıştır. Böylece araştırmacı günlüğü ve öğrenci ürünlerinden elde edilen bulguların birlikte sunulmasına zemin hazırlanmıştır.

Araştırmanın bu bölümünde ilk haftadan itibaren kayıt altına alınan araştırmacı günlüğü ve öğrenci ürünlerine ilişkin bulgular sunulmaktadır. Araştırmanın ilk döngüsünde öğrencilerin kart gösterme tekniğine grup olarak yüksek oranda doğru cevap verdikleri görülmüştür. Bu durum, ilk haftadaki konuların öğrenciler tarafından kavrandığını gösteren önemli bir bulgu olarak karşımıza çıkmaktadır. Araştırmacı günlüğüne yansıyanlar şöyledir:

"Değerlendirme sürecinde kart gösterme tekniğinden yararlanıldı. Öğrencilere sirasılyla sorular akıllı tahtada sunularak grup içinde 1 dakika tartışmaları ve ardından cevapların söylemeleri istendi. ... Değerlendirme sonunda tüm gruplarn doğru yanıt sayıları hesaplandı ve tüm gruplar alkışlandı. Birinci ve ikinci grubun 11, üçüncü ve dördüncü grubun 10 ve son grubun ise 12 soruya da doğru cevap verdiği görüldü" (1. hafta, 10 Kasım 2017).

Araştırmanın ikinci haftasının değerlendirme bölümünde probleme dayalı öğrenme sürecinde tasarlanan posterlerin farklı gruplar tarafından değerlendirmesi yapıldı. Öğrenciler tarafından yapılan değerlendirme sonucunda tüm grupların 
posterlerinde birkaç eksiklik dışında tüm bilgilerin doğru olduğu görüldü. Araştırmacı günlüğüne yansıyanlar şöyledir:

“... Ardından öğrencilerin buldukları çözümler poster olarak sınıf duvarlarına asıldı. Böylece gruplarm sirasıyla posterleri değerlendirmeleri istendi. Poster değerlendirmesi sonucunda neredeyse tüm gruplarm Türklerin iklimi, giyim tarzlar, ekonomik faaliyetleri, konaklama yerleri ve şekillerine yönelik doğru bilgiler kullandıkları görüldü" (2. Hafta, 17 Kasım 2017).

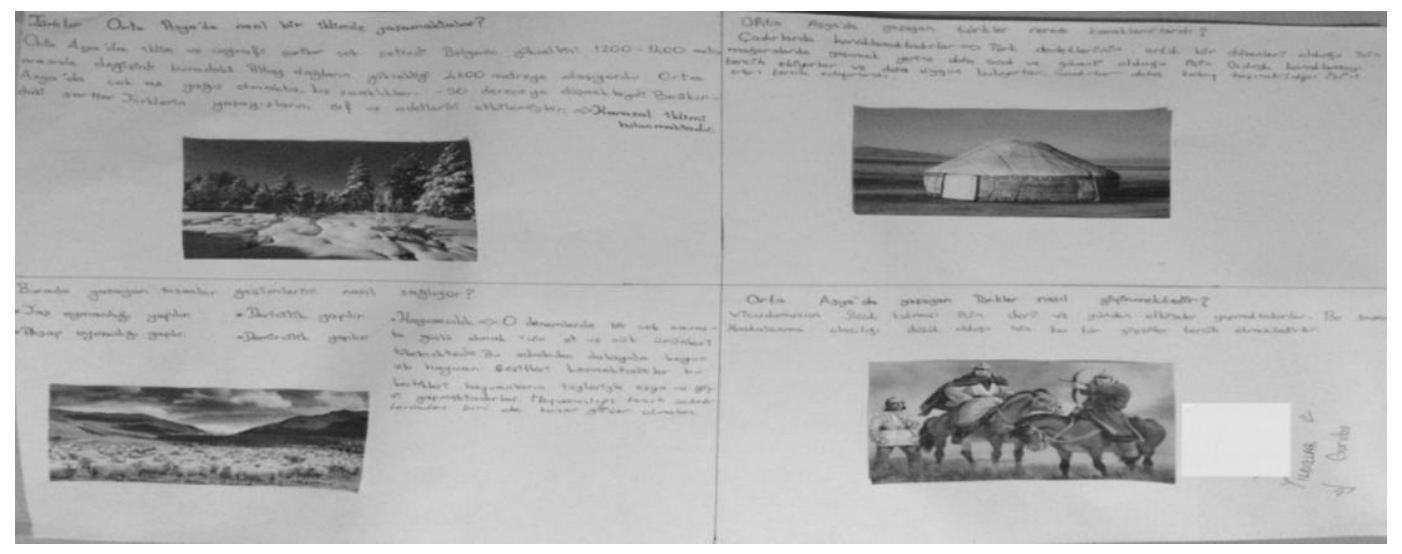

Şekil 2. Probleme dayalı öğrenme süreci sonucunda tasarlanan poster örneği

Araştırmanın üçüncü haftasında öğrencilerin kendilerine sunulan çoktan seçmeli ve doğru-yanlış işaretlemeli ölçme-değerlendirme araçlarına yüksek sayıda doğru cevap verdikleri görülmüştür. Bu durum, üçüncü haftada kazandırılması istenilen hedefin öğrenciler tarafından benimsendiğinin önemli bir göstergesidir. Araştırmacı günlüğüne yansıyanlar şöyledir:

"Dersin değerlendirme sürecinde, öğrenciler daha önceki haftalarda bulunduklar gruplara ayrilarak, kendilerine sunulan sorulara grup üyeleriyle tartışarak cevap vermeleri istendi. Hem çoktan seçmeli, hem de doğru-yanlış sorularının bulunduğu test sonucunda birinci ve dördüncü grup hariç, diğer grupların tüm sorulara doğru cevap verdikleri görüldü. Bu durum, hem ders içi katılımlar hem de ders sonu değerlendirmeleri göz önüne alındığında öğrencilerin akademik başarılarının yükseldiği savını desteklemektedir" (3. Hafta, 24 Kasım 2017).

Araştırmanın uygulama sürecinin dördüncü haftasında öğrencilerden kompozisyon yazmaları istendi. İlk olarak kompozisyonun kapsamı öğrencilere belirtildi ve yazmaları için süre verildi. Öğrencilerin yazdıkları kompozisyonlar ders süreci sonunda topland1. Eylem grubuyla birlikte analiz edildi. Analiz sonucunda öğrencilerin, İpek Yolu'na ilişkin hem siyasal hem kültürel hem de ekonomik birçok özelliği belirttikleri görüldü. Bu kapsamda, araştırmacı günlüğüne ve öğrenci ürünlerine yansıyanlar şöyledir:

"Son derste ise öğrencilerin İpek Yolu'na ilişkin kompozisyonlarının oluşturulmasına süre ayrıldt. İlk olarak kompozisyon yazılacak kâğıtlar öğrenciler dağıtıldl, ardından ise "İpek Yolu'nda bir tüccar olarak yaşadıklarınız yazınız" yönergesi verildi. Böylece öğrenciler tarafindan İpek Yolu'nun çeşitli özelliklerinin öğrenilmesi durumu tek bir metin üzerinde değerlendirilecekti" (4. Hafta, 1 Aralk 2017). 


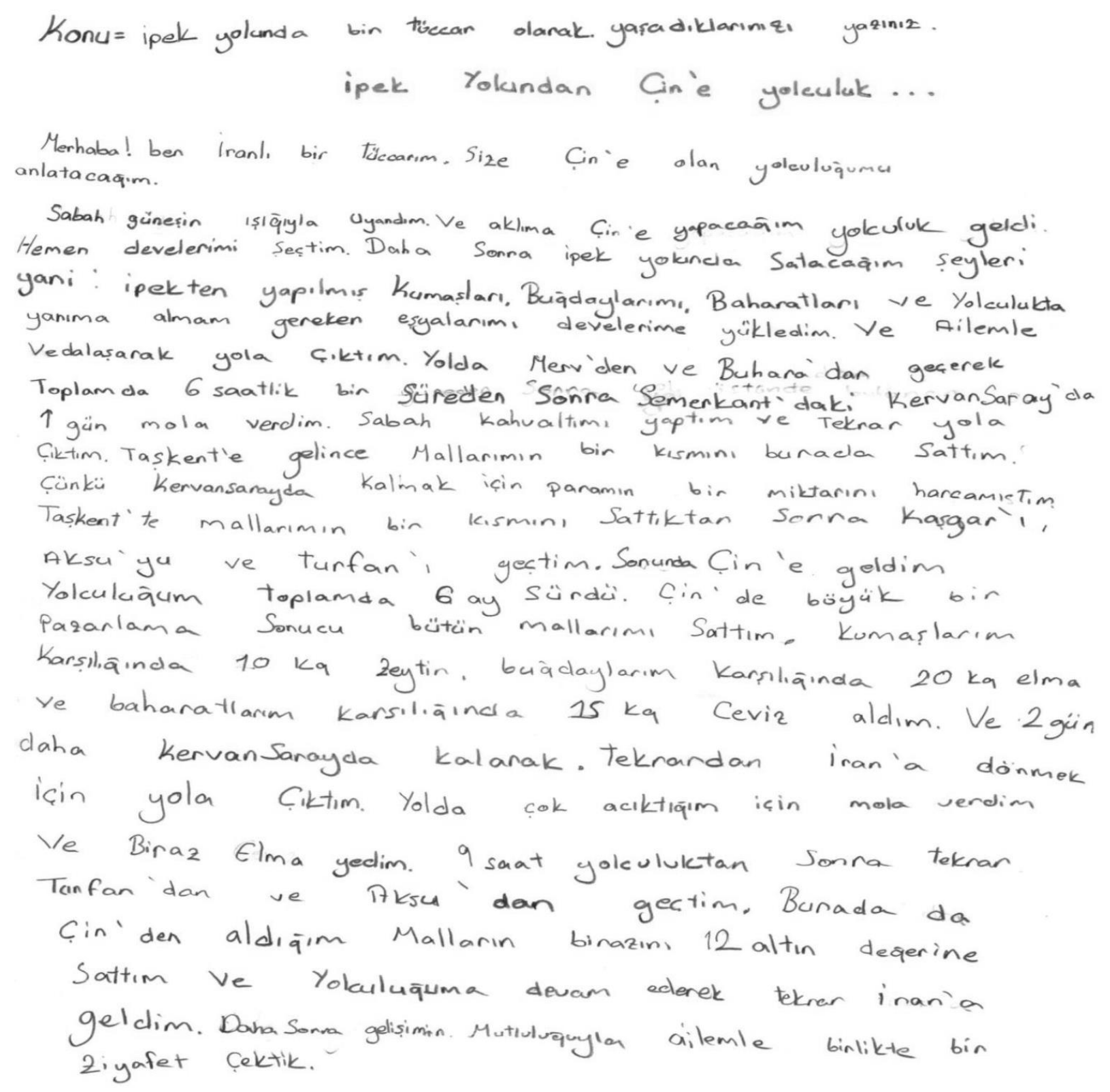

\section{Şekil 3. İpek Yolu kompozisyon örneği}

Beşinci haftada öğrenciler gruplara ayrılarak, tarih şeridi oluşturma etkinliği yapıld1. Böylece öğrencilerin İslamiyet'in doğuş ve yayılış sürecine ilişkin hem olayları hem bu olayların içeriğini hem de tarihlerini bilmeleri sağlanmak istendi. Dersin değerlendirme kısmında ise gruplar tarafından tasarlanan tarih şeritleri değerlendirildi. Değerlendirme sonucunda öğrenci başarılarının iyi bir düzeyde olduğu görüldü. Araştırmacı günlüğü ve öğrenci ürünlerine yansıyanlar şunlardır:

"... Süre bitti ifadesiyle süreç tamamlandı. Bitirilen tarih şeritleri tahtaya asıldı. Böylece değerlendirme sürecine geçildi. Her tarih şeridi sinıfla birlikte değerlendirildi. Böylece öğrencilerin eksik ve yanlış bilgileri giderildi. Süreç sonunda tüm gruplar aynı puanı aldılar. Her grup 14 maddeden 12'sini doğru yapmıştı" (5. hafta, 8 Aralık 2017). 


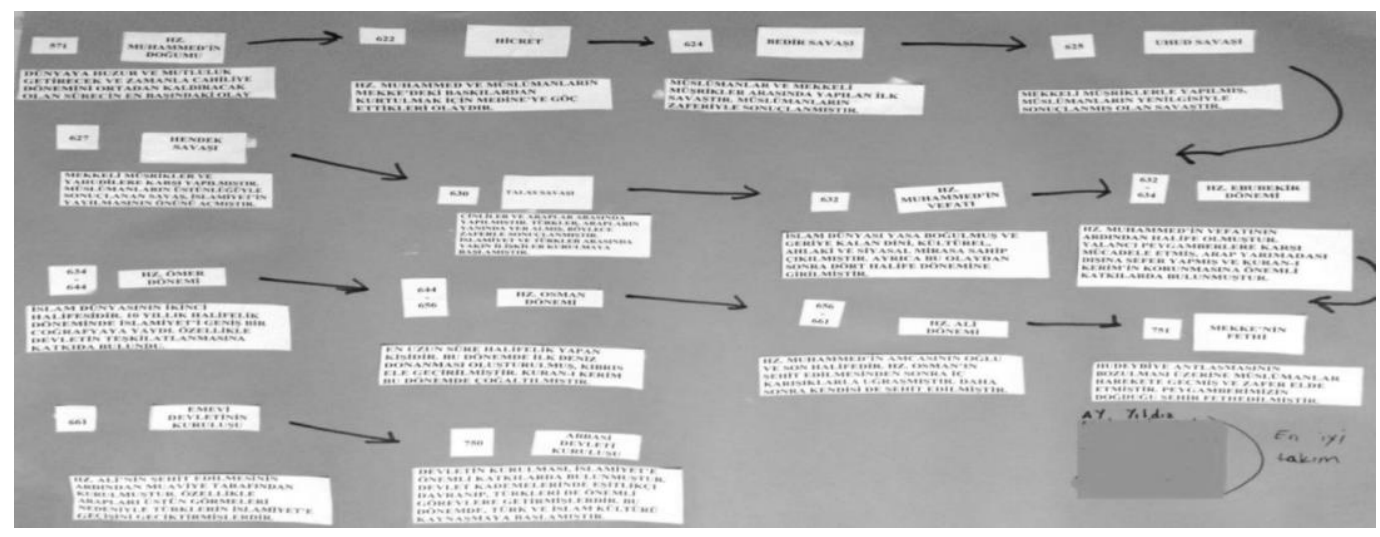

Şekil 4. Öğrenciler tarafından tasarlanan tarih şeridi örneği

Araştırmanın altıncı haftasında, önceki haftalarda gerçekleştirilen rol oynama sürecinin farklı bir uygulanışı olan ve öğrencilerin oldukça keyif aldığı tarihsel empati yönteminden yararlanıldı. Dersin değerlendirme süreci ise oyunlaştırma sürecine uygun olarak, tüm sınıfın katılımıyla gerçekleştirildi. Sınıfta çember şeklinde oturtulan öğrenciler, öğretmenin sürecin değerlendirmesine yönelik sordukları sorulara yoğun bir katılım gösterdiler ve birçoğu doğru cevaplar verdi. Araştırmacı günlüğüne yansıyanlar şöyledir:

"Dersin değerlendirme noktasında öğrencilerle, yaratıcı drama süreçlerinde olduğu gibi bir değerlendirme süreci yürütüldü. Öğrenciler, sinıf ortasında çember şeklinde oturtuldu, öğretmen de bu çemberde yer aldr. Ardindan öğrencilere, İslamiyet öncesi dönem ve İslamiyet dönemi siyasal, sosyal ve kültürel alanlarda gerçekleştirilen uygulamalara ilişkin sorular soruldu. Öğrencilerin neredeyse tümü bu sorulara parmak kaldırdı ve birçoğu da doğru cevap verdi. Eksik kalan cevaplara da öğretmen kendi yorumunu getirerek, öğrencilerin bilgilerini tamamlamasına yardım etti. Böylece tarihsel empati sürecinin bir değerlendirmesi yapıldı" (6. hafta, 15 Aralık 2017).

Araştırmanın yedinci haftasında, dersin değerlendirmesinde eşleştirme testinden yararlanıldı. Öğrencilerin bireysel olarak yanıtlamaları gereken teste verdikleri cevaplar incelendiğinde yüksek puanlar aldıkları görüldü. Araştırmacı günlüğüne yansıyanlar şöyledir:

"Dersin değerlendirme noktasında, eşleştirme testlerinden yararlanıldı. İlk Türk-İslam devletleriyle ilgili olan eşleştirme testinde kazandırlması gereken tüm devletler ve ünlü şahsiyetlerine ilişkin öncüller yer aldı. Öğrencilere testlerin kendileri tarafindan okunacağı söylendikten sonra heyecanlandıkları görüldü. Tüm öğrenciler, eşleştirme testlerini istekli bir şekilde cevapladılar. Ardından testlerin isim yazan kısımları kapatıldl, harmanlanarak farklı kişilere dağıtıldı. Öğrenciler, cevap anahtarına uygun olarak arkadaşlarının yanıtlarını değerlendirdiler. Eşleştirme testi 12 eşleştirme maddesinden oluşmaktaydı. Değerlendirme sonucunda, öğrencilerin doğru cevap sayılarının 8 ve 12 arasında değiştiği görüldü" (7. hafta, 22 Aralik 2017).

Sekizinci haftada dersin değerlendirme kısmında öğrencilerden kompozisyon yazmaları istendi. Böylece tören ve kutlamamızdaki değişimin nedenleri ortaya çıkarılmak istendi. Bu kapsamda, araştırmacı günlüğünde kayıt altına alınan bulgular şöyledir:

"Öğrencilerin kompozisyonlar ders süreci sonunda toplandı. Okul saati sona erdikten sonra ise eylem grubunda incelendi. Öğrencilerin kompozisyonlarında tören ve kutlamalarımızdaki nedenlere dair birçok vurgu görüldü. Özellikle teknolojinin gelişmesi öğrencilerin görüşleri arasinda önemli bir yer tuttu" (8. Hafta, 29 Aralik 2017). 


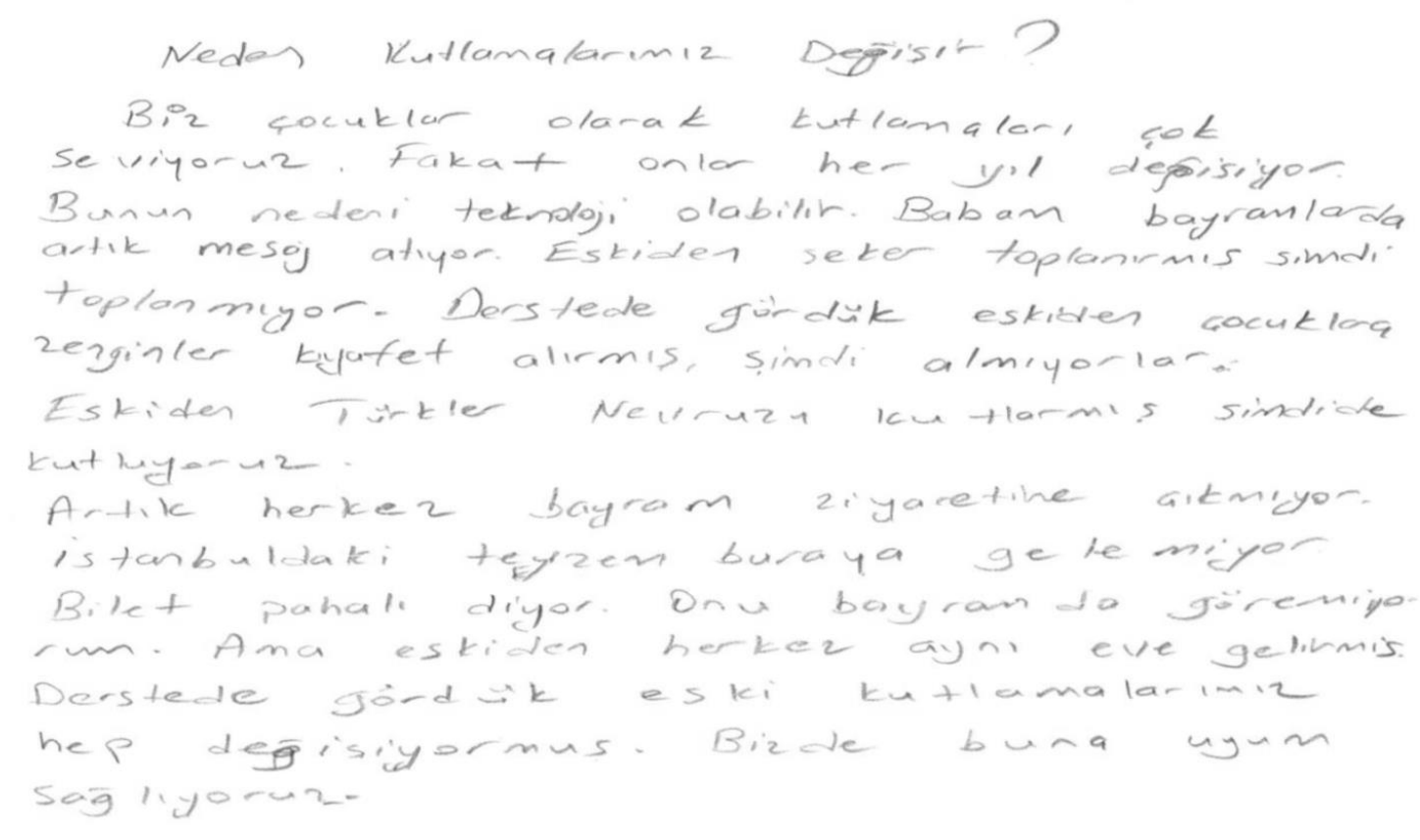

Şekil 5. Tören ve kutlamalarımıza ilişkin kompozisyon örneği

Araştırmanın son haftası olan dokuzuncu haftada öğrencilerin ders sonu başarılarını belirlemek için tartışma yöntemi kullanılmıştır. Bu kapsamda, öğrenciler birbirlerine dönük olarak oturtuldu, tartışmanın nasıl gerçekleştirileceği kendilerine anlatıldı ve tüm öğrencilerin katılımıyla tartışma gerçekleştirildi. Araştırmacı günlüğüne yansıyanlar şu şekildedir:

“Son haftaki dersin değerlendirme kısmında öğrencilerle bir tartışma ortamı oluşturuldu. Böylece öğrencilerin uygulama sürecinin başından itibaren edindikleri kültürel ögelerimiz tartışıldı. Özellikle kültürel ögelerimizin değişimi noktasında öğrenciler teknolojiyi sıklkkla vurguladılar. Öğrencilerden biri, "Eskiden babam, bayramlarda biz hep ev ev gezerdik diyor. Artık hep mesaj atıyoruz", diye görüş belirtti. Tüm öğrencilerin katılımıyla yürütülen süreç sonucunda öğrencilerin birçok soyut ve somut kültürel unsuru belirttikleri ve değişimin nedenlerine yönelik de iyi bir bakış açısı geliştirdiklerine ulaşıldı" (9. hafta, 5 Ocak 2018).

\section{Tartışma, Sonuç ve Öneriler}

Araştırmanın bulguları incelendiğinde, araştırmaya dâhil edilen öğrencilerin sosyal bilgiler dersine yönelik akademik başarılarında dikkate değer bir gelişim yaşandığına ulaşılmıştır. Bu kapsamda ortaya çıkan sonuçlar aşağıda sunulmuştur.

1. Araştırmanın akademik başarı testi verileri incelendiğinde, öğrencilerin İpek Yolu'nda Türkler Ünitesi başarılarının anlamlı bir şekilde arttı̆̆ına ulaşılmıştır. $\mathrm{Bu}$ açıdan bakıldığında, öğrencilerin akademik başarı testine yönelik öntest ve sontest puanları arasında anlamlı bir farka rastlanmıştır. Bu durum, ters yüz edilmiş sınıf modeli aracılığıyla sürdürülen ders sürecinin öğrencilerin akademik başarılarını arttırdığının bir kanıtıdır.

2. Öğrencilerin öntest ve sontest fark puanlarına bakıldığında ise, 36 ve 54 puan aralığında bir artışın olduğu sonucuna ulaşılmıştır. Bu durum, öğrencilerin araştırma öncesi İpek Yolu'nda Türkler Ünitesi'ne yönelik akademik başarılarının ters yüz edilmiş sınıf modelinin uygulanmasıyla birlikte dikkat değer bir şekilde arttığının diğer bir göstergesidir. 
3. Öğrencilerin akademik başarılarını ortaya çıkarmayı amaçlayan diğer veri toplama araçlarına ilişkin ulaşılan sonuçlar incelendiğinde de akademik başarı testiyle tutarlı sonuçlara rastlanmıştır. Bu kapsamda, hem araştırmacı günlüğüne hem de öğrenci ürünlerine yansıyan akademik başarı ile ilgili veriler incelendiğinde, öğrencilerin aktif öğrenme temelli ders sürecine yoğun katılım gösterdikleri, bunun bir sonucu olarak da ders sonu değerlendirmelerde yüksek bir başarı sergilediklerine ulaşılmıştır. Bu sonuç, sadece akademik başarı testiyle değil, diğer veri toplama araçlarıyla da öğrencilerin akademik başarılarındaki gelişimin önemli bir göstergesidir.

Alan yazına bakıldı̆̆ında, bu araştırmanın sonuçları destekleyen ve tam ters yönde sonuçlara ulaşan birçok araştırmanın bulunduğu görülmüştür. Bu durum, ters yüz edilmiş sınıf modelin planlama ve uygulama niteliğinin öğrencilerin akademik başarılarını etkilediği şeklinde değerlendirilebilir. Ters yüz edilmiş sınıf modelinin akademik başarıyı arttırdığı savını destekleyen bir sonuç, Boon, Burke, Fore ve Hagan-Burke (2006) tarafından yapılan çalışmada ortaya çıkmıştır. Araştırmacılar, sosyal bilgiler kaynaştırma sınıfında öntest ve sontest kontrol gruplu yarı deneysel desende öğrencilerin sosyal bilgiler dersi içeriğini kavrama düzeylerini incelemişlerdir. Araştırma sonucunda, deney grubunda yer alan bilgisayar destekli zihin haritası ve ters yüz edilmiş sınıf modelinin uygulandığı deney grubu öğrencilerinin, geleneksel ders kitabıyla öğrenim gören kontrol grubu öğrencilerine göre sosyal bilgiler dersi içeriğini daha fazla kavradıkları ortaya çıkmıştır. Bunu destekleyen bir araştırma ise Unal ve Unal (2017) tarafından gerçekleştirilmiştir. Araştırmacılar çalışmaları sonucunda, ters yüz edilmiş sınıf modelinin, geleneksel öğretime göre öğrencilerin akademik başarılarını arttırdığı sonucuna ulaşmışlardır. Aidinopoulou ve Sampson (2017) tarafından sosyal bilgiler dersinde gerçekleştirilen çalışmada ise araştırılan noktalardan birisi öğrencilerin tarihi içeriği hatırlama başarılarını ortaya çıkarmak olarak belirtilmiştir. Araştırmacılar, öğrencilerin tarihi içeriği hatırlama başarılarının, geleneksel öğretim sürecinde öğretmenin daha fazla teorik bilgi aktarmasına rağmen ters yüz edilmiş sınıf modeliyle yürütülen öğretim sürecine katılan öğrencilerin başarılarının büyük bir fark olmamasına rağmen, düşük pozitif etkide daha yüksek olduğuna ulaşılmıştır.

Yukarıdaki sonuçların tam tersi yönde bir sonuca ise ters yüz edilmiş sınıf modeliyle öğrencilerin başarılarını geliştirmeyi amaçlayan bir çalışma olan ve Snyder, Besozzi, Paska ve Oppenlander (2016) tarafından gerçekleştirilen araştırmada rastlanılmıştır. Araştırmacılar çalışmalarının sonucunda, bu çalışmada ortaya çıkan sonuçların aksine ters yüz edilmiş sınıf modelinin öğrencilerin akademik başarılarını arttırmada başarılı olamadı̆̆ını belirtmişlerdir. Pozolinski (2015) tarafından yürütülen çalışmada, ortaokul öğrencilerinin sosyal bilgiler dersine yönelik başarılarının ters yüz edilmiş sınıf modeliyle birlikte geleneksel öğretime göre yükselme durumu araştırılmıştır. Araştırma sonucunda, öğrenciler arasında sosyal bilgiler dersi başarıları açısından dikkate değer bir farka rastlanmadı̆̆ına ulaşılmıştır. Smith (2015) de karma yöntem kapsamında yürüttüğü çalışmasında, ters yüz edilmiş sınıf modelinin öğrenci başarılarını geliştirmediğini, aksine geleneksel öğretime devam eden öğrencilerin ödevlerini tamamlama oranlarının daha yüksek olduğuna ulaşmıştır. 
Tüm bu araştırmalar, ters yüz edilmiş sınıf modelinin hem öğrenci başarısını arttırabildiğini, hem de başarıyı geliştirmede bir etki yaratamadığını ortaya çıkarmaktadır. Bu durumun nedenleri arasında, öğretmenin ters yüz edilmiş sınıf sürecini iyi bir şekilde planlama ve yürütebilme becerisi, öğrencilerin sürece aktif bir şekilde katılması, tüm öğrenciler için yeterli teknolojik destek imkânların sağlanması, ebeveynlerin ters yüz edilmiş sınıf modeline yönelik bakış açıları vb. gösterilebilir. Sıralanan bu unsurlar nitelikli bir şekilde gerçekleştirilmeli ve harmanlanmış öğrenme ortamları günümüz öğretim ihtiyaçlarına cevap verebilmelidir.

$\mathrm{Bu}$ araştırma, eylem araştırmasıyla desenlendiğinden dolayı ters yüz edilmiş sınıf modelinin etkililiğinin test edilmesinde deneysel çalışmalara ihtiyaç duyulmaktadır. Buna ek olarak, farklı sınıf ve yaş düzeylerinde araştırmaların gerçekleştirilmesi de gerekli görülmektedir. Böylece modelin etkililiği daha net bir şekilde test edilebilir. Ayrıca ters yüz edilmiş sınıf modelinin uygulama sürecinin değerlendirilmesi durum çalışması gibi nitel araştırma desenleriyle sağlanarak, uygulama sürecinin niteliği arttırılabilir. Son olarak, karma yöntem araştırmalarıyla hem nicel hem de nitel paradigmanın etkili veri toplama araçları birleştirilerek, ters yüz edilmiş sınıf modeline ilişkin bütünsel araştırmalar gerçekleştirilebilir.

\section{Kaynakça}

Aidinopoulou, V. and Sampson, D. G. (2017). An action research study from implementing the flipped classroom model in primary school history teaching and learning. Journal of Educational Technology E Society, 20(1), 237-247.

Akgün, M. ve Atıcı, B. (2016). Ters-düz sınıfların öğrencilerin akademik başarısı ve görüşlerine etkisi. Kastamonu Ĕ̆itim Dergisi, 25(1), 329-344.

Arkorful, V. and Abaidoo, N. (2015). The role of e-learning, advantages and disadvantages of its adoption in higher education. International Journal of Instructional Technology and Distance Learning, 12(1), 29-42.

Berg, B. L. (2001). Oualitative research methods for the social sciences (4th edition). United States of America: Pearson.

Bonk, C. J., ve Graham, C. R. (Eds.). (2006). Handbook of blended learning: Global perspectives, local designs. San Francisco, CA: Pfeiffer.

Boon, R. T., Burke, M. D., Fore, C. and Hagan-Burke, S. (2006). Improving student content knowledge in inclusive social studies classrooms using technologybased cognitive organizers: A systematic replication. Learning Disabilities: A Contemporary Journal, 4(1), 1-17.

Bouhnik, D. and Marcus, T. (2006). Interaction in distance-learning courses. Journal of the American Society for Information Science and Technology, 57(3), 299-305. https:// doi.org/10.1002/asi.20277

Cochran-Smith, M. and Lytle, S. L. (1993). Inside outside: Teacher research and knowledge. New York: Teacher College.

Creswell, J. W. (2013). Araştırma deseni: Nitel, nicel ve karma yöntem yaklaşımları (S. B. Demir, Çev. Ed.). Ankara: Eğiten Kitap.

Cukurbasi, B. ve Kiyici, M. (2017). Preservice teachers' views about flipped classroom model. Bayburt Ĕ̆itim Fakültesi Dergisi, 12(23), 87-102. 
Çakır, E. ve Yaman, S. (2017). Fen bilimleri dersinde ters yüz sınıf uygulamalarının öğrencilerin fen başarıları ve zihinsel risk alma becerilerine etkisi. Fen Bilimleri Öğretim Dergisi, 5(2), 130-142.

Dağ, F. (2011). Harmanlanmış (karma) öğrenme ortamları ve tasarımına ilişkin öneriler. Ahi Evran Üniversitesi Ĕ̆itim Fakültesi Dergisi, 12(2), 73-97.

Demiralay, R. (2014). Evde ders okulda ödev modelinin benimsenmesi sürecinin yeniliğin yayılımı kuramı çerçevesinde incelenmesi (Doktora Tezi). Gazi Üniversitesi Eğitim Bilimleri Enstitüsü, Ankara.

Driscoll, M. (2002). Blended learning: Let's get beyond the hype. E-Learning, 3(3), 1-3.

Erdogan, E. ve Akbaba, B. (2018). Should we flip the social studies classrooms? The opinions of social studies teacher candidates on flipped classroom. Journal of Education and Learning, 7(1), 116-124. https://doi.org/10.5539/jel.v7n1p116

Friesen, N. (2012). Report: Defining blended learning. Retrieved from http:/ / learningspaces.org/papers/Defining_Blended_Learning_NF.pdf.

Garrison, D. R. ve Kanuka, H. (2004). Blended learning: Uncovering its transformative potential in higher education. The Internet and Higher Education, 7(2), 95-105. https://doi.org/10.1016/j.iheduc.2004.02.001

Gençer, B. G. (2015). Okullarda ters-yüz sınıf modelinin uygulanmasına yönelik bir vaka çalışması (Yüksek Lisans Tezi). Bahçeşehir Üniversitesi Eğitim Bilimleri Enstitüsü, İstanbul.

Glesne, C. (2015). Nitel araştırmaya giriş (A. Ersoy ve P. Yalçınoğlu, Çev. Ed.). Ankara: An1.

Göğebakan-Yıldız, D., Kıyıcı, G., ve Altıntaş, G. (2016). Ters-yüz edilmiş sınıf modelinin öğretmen adaylarının erişileri ve görüşleri açısından incelenmesi. Sakarya University Journal of Education, 6(3), 186-200. https:/ / doi.org/10.19126/suje.281368

Greenwood, D. J. and Levin, M. (2007). Introduction to action research: Social research for social change (second edition). California: Sage.

Gürgür, H. (2016). Eylem araştırması. A. Saban ve A. Ersoy (Ed.). Eğitimde nitel araştırma desenleri içinde (s. 3-50). Ankara: Anı.

Hultén, M. ve Larsson, B. (2016). The flipped classroom: Primary and secondary teachers' views on an educational movement in schools in Sweden today. Scandinavian Journal of Educational Research, 62(3), 1-11. https:// doi.org/10.1080/00313831.2016.1258662

Hwang, G. J., Lai, C. L. ve Wang, S. Y. (2015). Seamless flipped learning: A mobile technology-enhanced flipped classroom with effective learning strategies. Journal of Computers in Education, 2(4), 449-473. https:// doi.org/10.1007/s40692-015-0043-0

Kocabatmaz, H. (2016). Ters yüz sınıf modeline ilişkin öğretmen adayı görüşleri. Ĕ̆itim ve Öğretim Araştırmaları Dergisi, 5(4), 14-24.

Köse, Y. ve Acar, E. (2017). Muhasebe eğitiminde modern yaklaşımlar: Ters yüz edilmiş sınıflar ve öğrencilerin yaklaşımı. Uluslararası Yönetim İktisat ve İşletme Dergisi, 13(5), 1049-1065. https:/ / doi.org/10.17130/ijmeb.2017icmeb1735887

Lage, M. J., Platt, G. J. and Treglia, M. (2000). Inverting the classroom: A gateway to creating an inclusive learning environment. The Journal of Economic Education, 31(1), 30-43. https://doi.org/10.2307/1183338 
Latif, S. W. A., Matzin, R., Jawawi, R., Mahadi, M. A., Jaidin, J. H., Mundia, L. and Shahrill, M. (2017). Implementing the flipped classroom model in the teaching of history. Journal of Education and Learning, 11(4), 373-380.

Lo, C. K. and Hew, K. F. (2017). A critical review of flipped classroom challenges in K-12 education: Possible solutions and recommendations for future research. Research and Practice in Technology Enhanced Learning, 12(4), 1-22. https:// doi.org/10.1186/s41039-016-0044-2

Love, B., Hodge, A., Corritore, C. and Ernst, D. C. (2015). Inquiry-based learning and the flipped classroom model. PRIMUS, 25(8), 745-762. https:/ / doi.org/10.1080/10511970.2015.1046005

Mcniff, J. (2000). Action research in organisations. Florence: Routledge.

Miles, M. B. and Huberman, A. M. (1994). Qualitative data analysis: An expanded sourcebook. California: Sage.

Mills, G. E. (2007). Action research: A guide for the teacher researcher (3th edition). New Jersey: Pearson.

Missildine, K., Fountain, R., Summers, L. ve Gosselin, K. (2013). Flipping classroom to improve student performance and satisfaction. Journal of Nursing Education, 52(10), 597-599. https://doi.org/10.3928/01484834-20130919-03

Molinari, D. (2003). The role of social comments in online problem solving groups (Doctoral Dissertation). Brigham Young University, Provo, UT.

Osguthorpe, R. T. and Graham, C. R. (2003). Blended learning systems: Definitions and directions. Quarterly Review of Distance Education, 4(3). 227-233.

Patton, M. Q. (2014). Nitel araştırma ve değerlendirme yöntemleri (M. Bütün ve S. Demir, Çev. Ed.). Ankara: Pegem.

Pozolinski, C. J. (2015). Effects of flipped classroom on student learning and attitudes in social studies. University of Wisconsin: Wisconsin Graduate School.

Robson, C. (2015). Bilimsel araştırma yöntemleri: Gerçek dünya araştırması (Ş. Çınkır ve N. Demirkasımoğlu, Çev. Ed.). Ankara: Anı.

Smith, J. P. (2015). The efficacy of a flipped learning classroom (Doctoral Dissertation). McKendree University, Illinois.

Snyder, C., Besozzi, D., Paska, L. and Oppenlander, J. (2016). Is flipping worth the fuss: A mixed methods case study of screencasting in the social studies classroom. American Secondary Education, 45(1), 28-45.

Snyder, C., Paska, L. M. and Besozzi, D. (2014). Cast from the past: Using screencasting in the social studies classroom. The Social Studies, 105(6), 310-314. https:/ / doi.org/10.1080/00377996.2014.951472

Talbert, R. (2012). Inverted classroom. Colleagues, 9(1), 1-3.

Tavşancıl, E. (2006). Tutumları ölçülmesi ve SPSS ile veri analizi. Ankara: Nobel Yayın Dağıtım.

Toffler, A. (2012). Üçüncü dalga. İstanbul: Koridor Yayıncılık.

Turan, Z. ve Göktaş, Y. (2015). Yükseköğretimde yeni bir yaklaşım: Öğrencilerin ters yüz sınıf yöntemine ilişkin görüşleri. Yüksekögretim ve Bilim Dergisi, 5(2), 156164.

Unal, Z. ve Unal, A. (2017). Comparison of student performance, student perception, and teacher satisfaction with traditional versus flipped classroom models. 
International Journal of Instruction, 10(4), 145-162.

https:// doi.org/10.12973/iji.2017.1049a

Unruh, T., Peters, M. L. and Willis, J. (2016). Flip this classroom: A comparative study. Computers in the Schools, 33(1), 38-58.

https:// doi.org/10.1080/07380569.2016.1139988

Yıldırım, A. ve Şimşek, H. (2013). Sosyal bilimlerde nitel araştırma yöntemleri. Ankara: Seçkin.

Zainuddin, Z. ve Attaran, M. (2016). Malaysian students' perceptions of flipped classroom: A case study. Innovations in Education and Teaching International, 53(6), 660-670. https:/ / doi.org/10.1080/14703297.2015.1102079

Winter, J. W. (2018). Performance and motivation in a middle school flipped learning course. TechTrends, 62, 176-183. https:/ / doi.org/10.1007/s11528-017-0228-7

\section{Summary}

\section{Introduction}

Efforts to adapt the technology to the teaching process have accelerated in recent years. In this context, a special emphasis is placed on removing the limitations of the teaching process and the teaching environment. To achieve this, blended learning, which serves the purpose of eliminating the disadvantaged aspects of both face-toface and distance education, comes to the forefront. Blended learning aims at combining face-to-face and distance learning. Within this scope, blended learning embodies lots of models. One of these is the flipped classroom model. This model has attracted attention in the field of education in recent years due to the fact that the teachers and academicians are more precise in the deficiencies of the face-to-face teaching process. Thus like many study area, social studies education also try to benefit from this model. Using the flipped classroom model, social studies educators think that they solve the in-class and out of class problems.

Although the flipped classroom model was revealed by Jonathan Bergmann and Aaron Sams in 2007-2008, the background of this model is based on earlier years. The process of implementing the flipped classroom model is almost opposite to the current traditional teaching process. In the teacher-centered traditional teaching process, the necessary information is transferred and the concepts are introduced in the class and the students are asked to complete their assignments at home. In the flipped classroom model, students face with the concepts and necessary content before they come to class. In the classroom, they complete their homework, solve problems related to the content they track and realize meaningful learning through active learning methods and techniques. In this context, it is thought that the implementation of flipped classroom model will contribute to social studies teaching process due to solve problems in social studies education such as lack of time, repetition problem, active learning disability, the presence of intensive content, acting on student learning speed. In this study, it is aimed to find out how the flipped classroom model changes the academic success of students in the "Turks in Silk Road" of 6th-grade social studies course. 


\section{Method}

This research was designed in accordance with the qualitative research approach. Because it is aimed to develop the academic success of students in social studies course with the flipped classroom model, action research which is one of the patterns of the qualitative research approach was utilized. Action research has been described in the literature from different perspectives. However, all these definitions appear to overlap with solve problems and improve the situation. In the study, purposive sampling method was used to determine the study group of the research. In this context, 21 students (11 males and 10 females) were included in total in the research process who continue their studies in the sixth grade and in a secondary school which is located in the Central Anatolia region of Turkey.

Following the determination of the study group, the action group of the study was formed. The action group consists of 1 academician, 1 researcher, and 2 teachers. Then, with the action group, an exchange of views was provided on how the students' success could be increased, and the 9-week action process was planned. The video lessons were delivered to the students through "edpuzzle.com" and the active learning methods/techniques were practiced in the classroom. Academic achievement test, researcher diary, and student products were used as data collection tools. In the analysis of the data, firstly, descriptive statistics and dependent group ttest were used for analysis of the quantitative data. Secondly, in the analysis of qualitative data, content analysis was employed in the context of systematic analytical analysis. Thus, it is aimed to reveal the hidden meaning within the data. Lastly, both quantitative and qualitative findings were combined, and data interpreted.

\section{Results}

Given the findings of the study, consistent results were found between different data collection tools. First of all, when the academic achievement test data were analyzed, it was found that the achievements of the students on the "Unit of Turks on the Silk Road" increased significantly. In addition, when the pre-test and post-test difference scores of the students were examined, it was concluded that there was an increase in the range of 36 and 54 points. Besides, when the results of the student products and the researcher diary, which are the other data collection tools aimed at revealing the students' academic achievements, were examined, it was found that the students' success was increased consistently with the academic achievement test. In the context of these results, it can be said that the flipped classroom model helps to increase the academic success of the social studies course with the differentiation of the teaching process.

\section{Authors' Biodata/Yazar Bilgileri}

Erdi ERDOĞAN Kırıkkale Üniversitesi Eğitim Fakültesi, Türkçe ve Sosyal Bilimler Eğitimi Bölümü'nde araştırma görevlisi doktor olarak görev yapmaktadır.

Erdi ERDOĞAN is a research assistant doctor at Kirıkkale University, Faculty of Education, Department of Turkish and Social Sciences Education. 
Bülent AKBABA Gazi Üniversitesi Gazi Eğitim Fakültesi, Türkçe ve Sosyal Bilimler Eğitimi Bölümü'nde doçent doktor olarak görev yapmaktadır.

Bülent AKBABA is an associate professor at Gazi University, Gazi Faculty of Education, Department of Turkish and Social Sciences Education. 